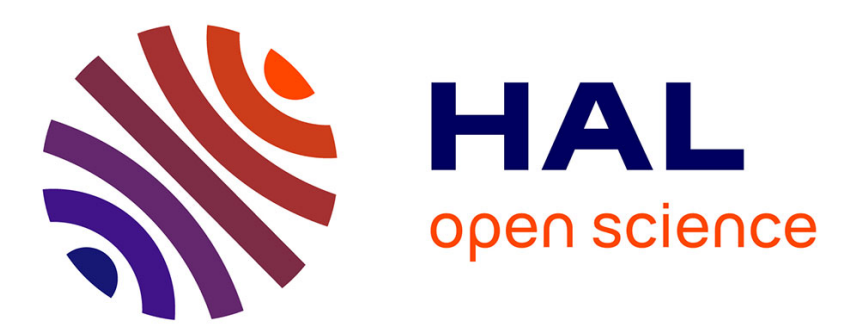

\title{
Mesoscale modeling of aeolian dust emission during the BoDEx 2005 experiment
}

Christel Bouet, Guy Cautenet, Richard Washington, Martin C. Todd, Benoit Laurent, Beatrice Marticorena, Gilles Bergametti

\section{To cite this version:}

Christel Bouet, Guy Cautenet, Richard Washington, Martin C. Todd, Benoit Laurent, et al.. Mesoscale modeling of aeolian dust emission during the BoDEx 2005 experiment. Geophysical Research Letters, 2007, 34 (7), pp.L07812. 10.1029/2006GL029184 . hal-02326031

\section{HAL Id: hal-02326031 \\ https://hal.science/hal-02326031}

Submitted on 22 Oct 2019

HAL is a multi-disciplinary open access archive for the deposit and dissemination of scientific research documents, whether they are published or not. The documents may come from teaching and research institutions in France or abroad, or from public or private research centers.
L'archive ouverte pluridisciplinaire HAL, est destinée au dépôt et à la diffusion de documents scientifiques de niveau recherche, publiés ou non, émanant des établissements d'enseignement et de recherche français ou étrangers, des laboratoires publics ou privés. 


\title{
Mesoscale modeling of aeolian dust emission during the BoDEx 2005 experiment
}

\author{
Christel Bouet, ${ }^{1}$ Guy Cautenet, ${ }^{1}$ Richard Washington, ${ }^{2}$ Martin C. Todd, ${ }^{3}$ Benoit Laurent, ${ }^{4}$ \\ Béatrice Marticorena, ${ }^{5}$ and Gilles Bergametti ${ }^{5}$
}

Received 22 December 2006; revised 20 February 2007; accepted 19 March 2007; published 14 April 2007.

[1] The Bodélé depression (Northern Chad) is believed to be the single largest source for the Saharan dust transported over the Atlantic Ocean, especially that emerging in the Gulf of Guinea in boreal winter. During the Bodélé Dust Experiment 2005 (BoDEx 2005), which was performed in February-March 2005, a severe dust event was observed and some of its main characteristics (surface wind, dust concentrations, radiation) were recorded. This paper tests the capability of a mesoscale model coupled online with a dust production model (DPM) to reproduce the small scale features associated to this dust event. These simulations clearly show that a spatial resolution of $10 \mathrm{~km} \times 10 \mathrm{~km}$ is required to reproduce satisfactorily the observed surface winds and the main characteristics of the dust plume. Citation: Bouet, C., G. Cautenet, R. Washington, M. C. Todd, B. Laurent, B. Marticorena, and G. Bergametti (2007), Mesoscale modeling of aeolian dust emission during the BoDEx 2005 experiment, Geophys. Res. Lett., 34, L07812, doi:10.1029/ 2006GL029184.

\section{Introduction}

[2] Recently, using Aerosol Index from Total Ozone Monitoring Spectrometer [Herman et al., 1997], Prospero et al. [2002] and Washington et al. [2003] identified the Bodélé depression (Northern Chad) as the most intense single Saharan dust source. This was confirmed by other satellite observations: Infrared Dust Difference Index [Brooks and Legrand, 2000], Multi-angle Imaging Spectroradiometer [Zhang and Christopher, 2003], or MODerate resolution Imaging Spectrometer [Koren and Kaufman, 2004]. Koren et al. [2006] estimate that $50 \%$ of the dust transport from Africa to the Amazon basin originates in the Bodélé.

[3] The Bodélé depression is a part of the ancient bed of Megachad Lake. It is located at the exit of the gap between the Tibesti (about $3000 \mathrm{~m}$ high) and the Ennedi mountains (about $1000 \mathrm{~m}$ high). At the exit of the gap, Washington and Todd [2005] highlighted the presence of a Low Level Jet (LLJ) in reanalysis data at $925 \mathrm{hPa}$ level that blows coincidently with the observed annual and intraseasonal dust transported from the depression. That particular meteorological situation,

\footnotetext{
${ }^{1}$ Laboratoire de Météorologie Physique, UMR CNRS 6016, Université Blaise Pascal, Aubière, France.

${ }^{2}$ Climate Research Laboratory, Centre for the Environment, Oxford University, Oxford, UK.

${ }^{3}$ Department of Geography, University College London, London, UK.

${ }^{4}$ Leibniz-Institute for Tropospheric Research, Leipzig, Germany.

${ }^{5}$ Laboratoire Interuniversitaire des Systèmes Atmosphériques, UMR CNRS 7583, Université Paris 7 et Université Paris 12, Créteil, France.
}

Copyright 2007 by the American Geophysical Union. 0094-8276/07/2006GL029184\$05.00 combined with the soil properties of the depression (diatomite sediment, as a majority) could explain the intense dust production observed throughout the year in this area.

[4] Modeling this LLJ is particularly difficult using global models. Koren and Kaufman [2004] revealed that the National Centers for Environmental Predictions (NCEP) reanalysis underestimates the velocities at $925 \mathrm{hPa}$ by a factor of 2 above the Bodélé region, a result broadly confirmed from in-situ observations [Washington et al., 2006; M. C. Todd et al., Regional model simulations of the Bodélé low-level jet of northern Chad during the Bodélé Dust Experiment (BoDEx 2005), submitted to Journal of Climate, 2006, hereinafter referred to as Todd et al., submitted manuscript, 2006]. As the frequency of dust emissions is controlled by the number of times the wind speed exceeds a threshold and as the dust flux depends on the third power of surface wind velocity, an underestimation of surface velocity leads to a large underestimation of dust emissions.

[5] This paper aims to test the capability of a mesoscale model (assumed to provide better resolved fields than global models) to retrieve the main features of a dust event that occurred during the Bodélé Dust Experiment (BoDEx) 2005.

\section{Field Experiment: BoDEx 2005}

[6] BoDEx 2005 [Washington et al., 2006; Todd et al., 2007] was a multidisciplinary field experiment conducted in the Bodélé region in Northern Chad during February and March 2005, the peak dust production season. This campaign was the first field campaign to study dust carried out in this region. The aim of BoDEx 2005 was to document the properties of dust and the mechanisms that account for the high dust emissions from the Bodélé region.

[7] The measurement site was located in Chicha $\left(16^{\circ} 52^{\prime} 50^{\prime \prime} \mathrm{N} 18^{\circ} 32^{\prime} 55.6^{\prime \prime} \mathrm{E}\right)$. Standard meteorological observations were performed with 2-minute intervals using automatic weather stations. Boundary layer wind speed and direction were measured using Pilot Balloons (PIBALs) tracking, except during dust events. A Cimel-318 photometer (identical to those used in the AErosol RObotic NETwork (AERONET) [Holben et al., 1998]) and microtops handheld photometers were used to characterize aerosol properties such as aerosol optical thickness (AOT), Angström exponent, or particle size distribution. For full details of the observational methods see Washington et al. [2006] and Todd et al. [2007].

[8] Two of the main results obtained during this campaign were the verification of the presence of the LLJ evident in the reanalysis data [Washington and Todd, 2005] and a quantification of the near surface winds 

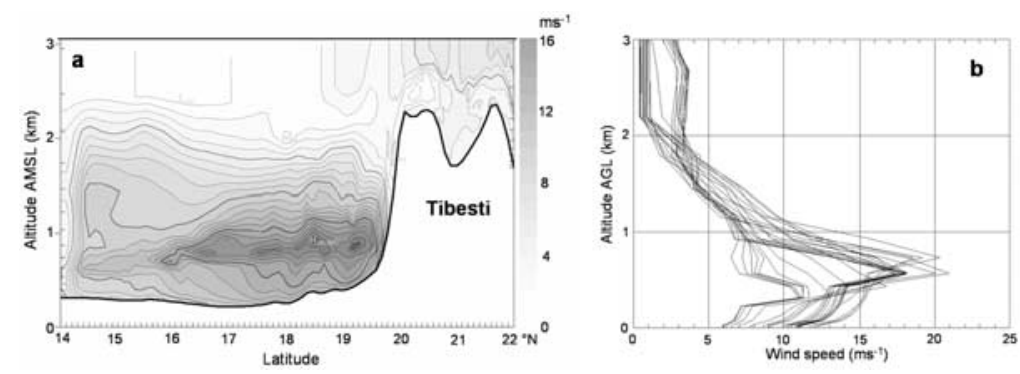

Figure 1. (a) Modeled LLJ meridional cross section $\left(18^{\circ} \mathrm{E}\right)$ on March 9, 12UTC, along the Tibesti southern slopes. (b) Modeled wind profiles at Chicha for the period March 7-13.

associated with dust emissions [Washington et al., 2006]. A pronounced diurnal cycle in wind velocity was observed, with a phase shift between the surface and boundary layer (i.e., the LLJ) such that at the surface, there is a maximum in the midmorning and a minimum at night; the reverse occurs in altitude for the LLJ core [Washington et al., 2006]. Moreover, speeds in excess of $16 \mathrm{~ms}^{-1}$ were measured (at $2 \mathrm{~m}$ agl) on dusty days [Washington et al., 2006]. Model experiments indicate that the inertial oscillation mechanism is responsible for the diurnal structure (Todd et al., submitted manuscript, 2006).

\section{Numerical Strategy}

[9] We use the Regional Atmospheric Modeling System (RAMS) mesoscale model v. 4.3 paralleled [Cotton et al., 2003], coupled online with the Dust Production Model (DPM) developed by Marticorena and Bergametti [1995].

[10] The RAMS model is a Eulerian, non-hydrostatic meteorological model featuring powerful facilities such as 4-Dimensional Data Assimilation (4DDA), interactive twoway nesting (up to 8 grids), bulk or detailed microphysics, and a comprehensive surface model. The model is initialized and laterally nudged by the reanalysis ECMWF (European Centre for Medium-Range Weather Forecasts) fields.

[11] The DPM works as follows. Each grid point of the modeled area is described by its physical features, the most important being the roughness length and the soil grain size distribution. Until recently, even though several soil grain size distributions may be present at each grid point, the model accounted for 5 soil types and the physical features of each soil type were available at a resolution of $1^{\circ} \times 1^{\circ}$. Since the work of Laurent [2005], the model accounts for 2 soil types only, which was proved to be sufficient since the spatial resolution of the surface features was increased to reach $0.25^{\circ} \times 0.25^{\circ}$. These surface feature parameters allow the estimation of the so-called "saltation flux", $G$, i.e., the horizontal flux mobilized by wind. Then, the horizontal flux gives rise to $F$, the vertical dust flux (constituted of small particles generated by the collisions between saltating grains and aggregates). The relationship between $F$ and $G$ is merely $F=\alpha G$, where $\alpha$ stands for a parameter which depends on the soil type. The contributions of each soil type to the total flux of a given grid point are added. This mass flux is eventually described along a fully spectral scheme: dust aerosol is distributed into 20 bins, ranging from 0.1 to $26 \mu \mathrm{m}$ in diameter. The initial spectral scheme derives from Alfaro and Gomes [2001]. Details on DPM can be found in the work of Marticorena and Bergametti [1995] and Marticorena et al. [1997].

[12] The DPM is coupled online with the RAMS model [Cautenet et al., 2000]: the winds velocities computed by the mesoscale model at the reference (or surface) level, say $10 \mathrm{~m}$ above surface, serves as input for the DPM. Dry and wet depositions of dust are accounted for in the model.

[13] The modeled domain is a grid centered on Faya $\left(18^{\circ} \mathrm{N}, 19^{\circ} \mathrm{E}\right)$. It ranges from $21.5^{\circ} \mathrm{N}$ to $14.4^{\circ} \mathrm{N}$ and from $13^{\circ} \mathrm{E}$ to $25^{\circ} \mathrm{E}$, i.e., its horizontal extent is $1200 \times 800 \mathrm{~km}^{2}$ with a horizontal resolution of $10 \mathrm{~km}$. There are 30 levels from ground to $22 \mathrm{~km}$ agl, with 10 levels from ground to $1.2 \mathrm{~km}$ in order to resolve the boundary layer well. According to Mass et al. [2002], "decreasing grid spacing in mesoscale model to less than $10-15 \mathrm{~km}$ generally improves the realism of the results". Considering this result, a preliminary work was undertaken to study the influence of horizontal grid resolution on wind fields in the Bodélé region. For the period of the BoDEx 2005 experiment, 3 horizontal resolutions were tested $(50,10$, and $5 \mathrm{~km})$ and the following conclusion was drawn: for this period, decreasing horizontal resolution to less than $10 \mathrm{~km}$ does not increase the agreement between measured and simulated wind velocity. The simulation runs from March 5 at 00 UTC to March 15 at $00 \mathrm{UTC}$, i.e., the major part of the BoDEx 2005 experiment and includes clear and dusty conditions (from 10 to 12 March 2005, there was a major dust event over the region under study).

[14] Comparison between modeled and experimental fields is achieved using the data set collected during BoDEx 2005 campaign in Chicha, along with some satellite data. We first compare the modeled wind velocities to the $0.5^{\circ} \times$ $0.5^{\circ}$ ECMWF surface data to characterize the above mentioned wind velocity underestimation which seems inherent to GCM outputs. Next, we compare the dust fluxes and concentrations to the available experimental data.

\section{Results and Discussion}

\subsection{Modeled Wind Field and Comparisons to Observations}

[15] As mentioned above, the main feature of the regional meteorology in the Bodélé region is the presence of a LLJ around $925 \mathrm{hPa}$ [Washington and Todd, 2005; Washington et al., 2006; Todd et al., submitted manuscript, 2006]. Figure 1a reports the simulated wind velocities between $14^{\circ} \mathrm{N}$ and $22^{\circ} \mathrm{N}$ at $18^{\circ} \mathrm{E}$ as a function of the altitude. It can be observed that a high wind speed nucleus develops near $900 \mathrm{hPa}$ (around $900 \mathrm{~m}$ on Figure 1a), especially between 

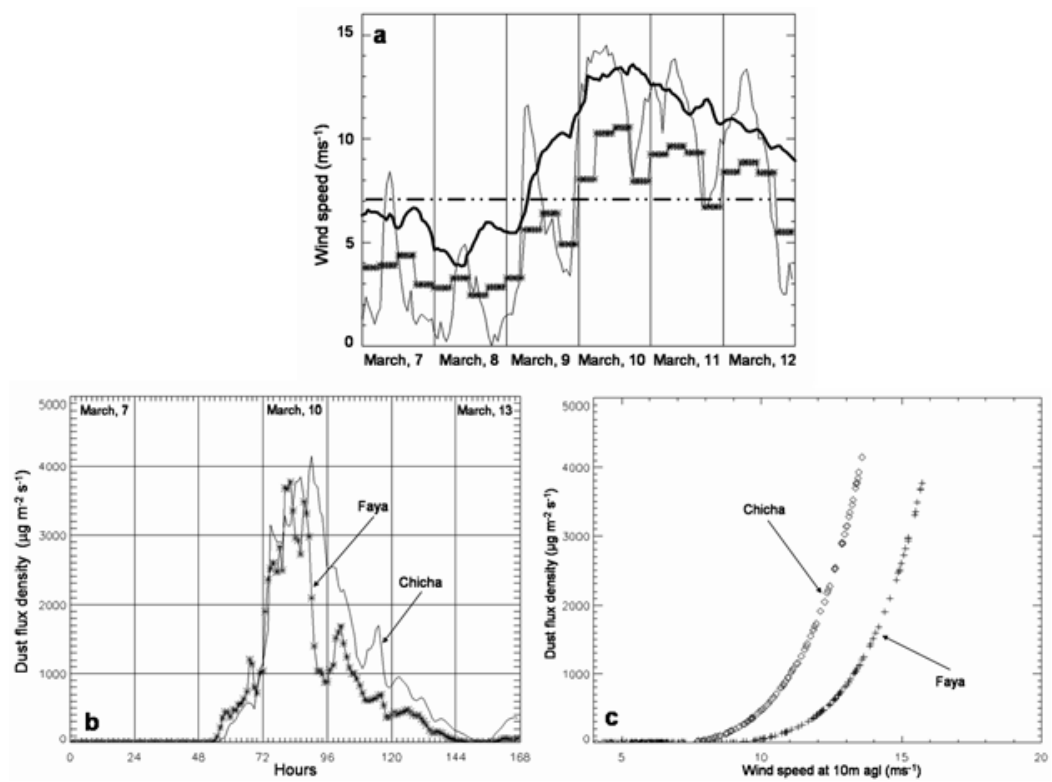

Figure 2. (a) Comparison between wind speed from ECMWF reanalysis data (stars), measurements (thin black line), and model (thick black line) at Chicha. Horizontal dash dotted line represents the wind speed threshold for emission at Chicha site according to the DPM. (b) Dust flux density modeled for the period from March 7 to March 13 at Chicha (solid line) and at Faya (stars). (c) Dust flux density as a function of wind at Chicha (diamonds) and Faya (crosses).

$16^{\circ} \mathrm{N}$ and $19^{\circ} \mathrm{N}$, i.e., downwind of the southern slopes of the Tibesti. This maximum wind speed nucleus is systematically present in the simulations corresponding to the period of the dust event $(\approx$ one week).

[16] The surface wind speed is obviously the most sensitive meteorological parameter for dust emissions, because (1) the dust emission occurs only when the local surface wind velocity threshold is exceeded and (2) the dust flux is proportional to the third power of the wind friction velocity [Marticorena and Bergametti, 1995]. Figure 2a shows that the modeled surface wind velocities (thick black line) well capture the magnitude of day-to-day variability of measured wind velocities (thin black line) in the region of Chicha. However, the diurnal cycle is less well resolved, a problem experienced in other model experiments [Tegen et al., 2006; Todd et al., submitted manuscript, 2006]. Figure 2a also points out that the ECMWF surface wind velocities (stars) are clearly underestimated, and hardly exceed the dust emission wind velocity threshold (dash dotted line, value $7.7 \mathrm{~ms}^{-1}$, as given by the DPM) at Chicha.

[17] A brief comparison between RAMS and ECMWF surface wind velocities is presented in Table 1 at Chicha and at Faya. In both locations, the RAMS maximum wind velocities are about $30 \%$ greater than those simulated by ECMWF, and the excess of the average RAMS value is at least $30 \%$. The number of cases the local wind velocity threshold for dust emission (given by the DPM) is exceeded, i.e., the number of time wind speed exceeds the minimum value from which dust can be emitted, is almost twice for RAMS as compared to ECMWF: the latter fails to retrieve the dust emission in about $45 \%$ of the cases.

\subsection{Modeled Dust Flux and Comparisons to Observations}

[18] Figure 2b displays the modeled dust mass flux density at Chicha and Faya. The intense dust episode occurs between March 9 and March 11, with the maximum concentration occurring on March 10 during daytime, as observed during the field campaign. The flux strength looks greater at Chicha, which may be explained by the lower wind velocity threshold for dust emissions: indeed, according to the DPM, the threshold is $9.3 \mathrm{~ms}^{-1}$ at Faya and only $7.7 \mathrm{~ms}^{-1}$ at Chicha. Figure 2c displays the modeled dust mass flux density at Chicha and Faya as a function of surface wind speed. It illustrates the greater sensitivity of dust emissions to wind velocity in the Chicha area than at Faya. Indeed, the former place is known as a dust "hot spot". By lack of in situ measurements, the simulated flux can only be indirectly validated by the concentrations estimates (see $\$ 3$ below). However, Todd et al. [2007] have estimated that the daily mass flux during this dust episode was about $1.2 \mathrm{Mt} /$ day in the exposed diatomite area. Over the same area and for the same period, our simulations estimate is about $1 \mathrm{Mt} /$ day, which is fairly equivalent. Using ECMWF wind fields as input for the DPM leads to a daily mass flux during this dust episode of about $0.4 \mathrm{Mt} /$ day, which is about 3 times less than the observed flux and about 2.4 times less than the flux estimated from RAMS. These large differences in mass flux estimates from RAMS and ECMWF data are not surprising: considering the results

Table 1. Comparison Between RAMS and ECMWF Surface Wind Velocities $(10 \mathrm{~m} \mathrm{agl})$ at Chicha and Faya During the Period March $7-13^{\mathrm{a}}$

\begin{tabular}{|c|c|c|c|c|c|c|}
\hline & \multicolumn{3}{|c|}{ RAMS } & \multicolumn{3}{|c|}{ ECMWF } \\
\hline & $\begin{array}{l}\mathrm{Vmax} \\
\mathrm{ms}^{-1}\end{array}$ & $\begin{array}{l}\text { Average } \\
\mathrm{V}, \mathrm{ms}^{-1}\end{array}$ & $\begin{array}{l}\text { Greater Than } \\
\text { Threshold, \% }\end{array}$ & $\begin{array}{l}\text { Vmax, } \\
\mathrm{ms}^{-1}\end{array}$ & $\begin{array}{l}\text { Average } \\
\mathrm{V}, \mathrm{ms}^{-1}\end{array}$ & $\begin{array}{l}\text { Greater Than } \\
\text { Threshold, \% }\end{array}$ \\
\hline Chicha & 13.6 & 9.0 & 67 & 10.5 & 6.2 & 36 \\
\hline Faya & 15.7 & 10.2 & 62 & 12.4 & 7.6 & 36 \\
\hline
\end{tabular}

${ }^{a}$ Maximum, average, and percentage of cases the local wind velocity threshold for dust emissions is exceeded. 

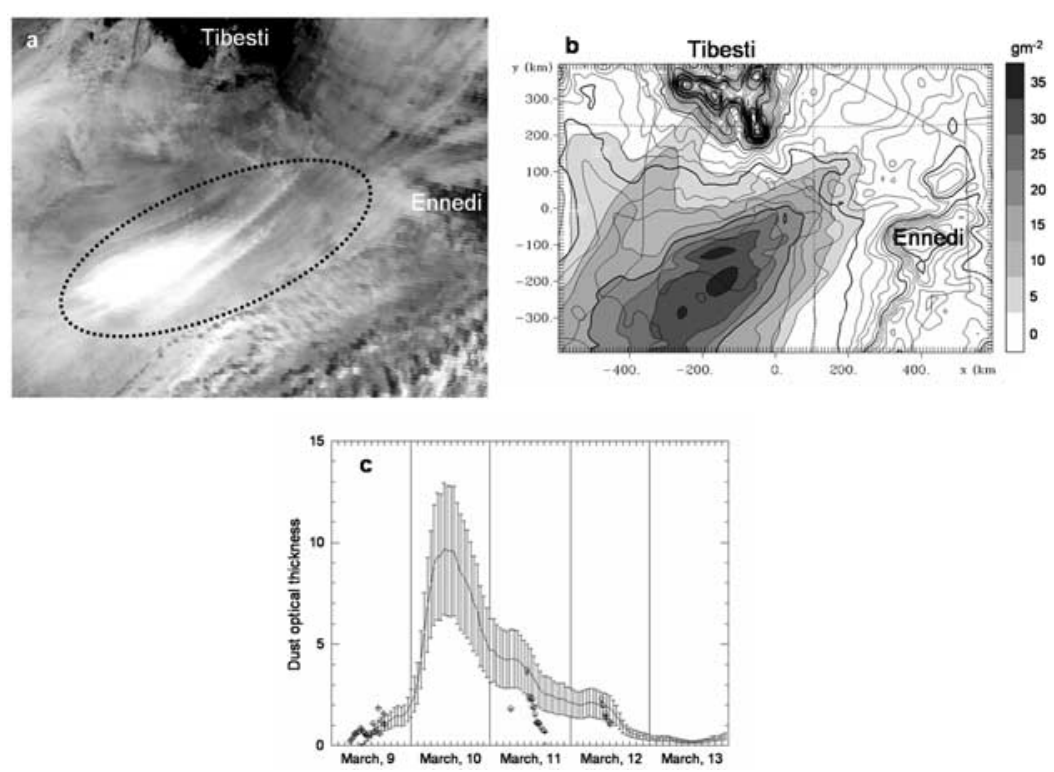

Figure 3. (a) MODIS Terra black and white image for March 11 at 0950 UTC. (b) Modeled dust concentration for March 11 at 1000 UTC. (c) Modeled optical depth from March 7 to March 13 at Chicha (black line) and corresponding radiometric (AERONET and microtops handheld photometers) data (diamonds for $440 \mathrm{~nm}$ and crosses for $670 \mathrm{~nm}$ ).

presented in Table 1, the underestimation of wind velocity in ECMWF results in a weaker dust mass flux than simulated by RAMS.

\subsection{Modeled Dust Field and Comparisons to Observations}

[19] In Figure 3a, we present the MODIS image (Terra) for March 11 at 1000 UTC whereas Figure 3b displays the modeled column dust load (vertical integration) at the same time. On a qualitative basis, the simulations reproduce quite well the dust emission area including its extension and the location of the most emitting places.

[20] On a quantitative basis, we have estimated the visible extinction at Chicha from the modeled column dust load. To do so, we calculated the dust optical thickness (DOT) by merely multiplying the modeled column dust load by the extinction coefficient for mineral aerosol. According to Tegen and Fung [1995], this extinction coefficient is between 0.2 and $0.4 \mathrm{~m}^{2} \mathrm{~g}^{-1}$ for particles with a diameter between $1-10 \mu \mathrm{m}$, which may be expected near source areas. Estimates by Foret et al. [2006] suggest that the extinction coefficient in source area (like Chicha site) could range from 0.1 to $0.2 \mathrm{~m}^{2} \mathrm{~g}^{-1}$ at $550 \mathrm{~nm}$. Figure $3 \mathrm{c}$ presents the simulated DOT for the period from March 7 to March 13. The central curve is the DOT considering an extinction coefficient of $0.15 \mathrm{~m}^{2} \mathrm{~g}^{-1}$; the error bars are obtained using the minimal and maximal values of the interval suggested by Foret et al. [2006]. Compared to the observed AOT for the same period (diamonds, AOT at $440 \mathrm{~nm}$; crosses, AOT at $670 \mathrm{~nm}$ ), the model results exhibit a satisfactory agreement: the range of modeled DOT generally captures measured AOT, with a tendency to overestimate AOT on March 11.

\section{Conclusion}

[21] Our purpose was to model a severe dust event in the Bodélé depression, recorded during the BoDEx 2005 experiment. This region of complex topography is respon- sible for intense dust plumes transported over the Sahel and the North-Atlantic Ocean and assumed to be one of the most active dust sources in the world [Prospero et al., 2002].

[22] To simulate the dust and dynamical observations, the RAMS model was coupled online with a dust production model [Marticorena and Bergametti, 1995]. Simulations performed with a spatial resolution of $10 \mathrm{~km} \times 10 \mathrm{~km}$ allows to retrieve the dynamical small scale features of the Bodélé region but also to reproduce the measured surface wind fields responsible for the local dust emissions. As a result, the simulated dust plume appears as consistent with satellite observation. From a quantitative point of view, the simulation reproduces the order of magnitude and the temporal variability of the measured aerosol optical thickness.

[23] This study illustrates the fact that a regional model with a spatial resolution of $10 \mathrm{~km} \times 10 \mathrm{~km}$ is able to capture the dust emission pattern in source regions of complex topography such as the Bodélé depression. For the studied dust event, the total dust emissions computed with the RAMS model are $40 \%$ higher than the emissions computed from ECMWF surface wind fields with a spatial resolution of $0.5^{\circ} \times 0.5^{\circ}$.

[24] Acknowledgments. This work was supported by the national program Chimie Atmosphérique (CHAT), a part of the Les Enveloppes Fluides et l'Environnement (LEFE) national program. This work makes use of the RAMS model, which was developed under the support of the National Science Foundation (NSF) and the Army Research Office (ARO). Computer resources were provided by CINES (Centre Informatique National de l'Enseignement Supérieur, project amp2106). We also wish to thank the computer team of the Laboratoire de Météorologie Physique of the Université Blaise Pascal (France): Anne-Marie Lanquette, Sandra Banson, and Philippe Cacault. The data used in this study (Figure 3a) were acquired as part of the NASA's Earth Science Enterprise. The algorithms were developed by the MODIS Science Teams. The data were processed by the MODIS Adaptive Processing System (MODAPS) and Goddard Distributed Active Archive Center (DAAC), and are archived and distributed by the Goddard DAAC. Finally, we thank B. Holben for his effort in establishing and maintaining the Bodélé AERONET site. 


\section{References}

Alfaro, S. C., and L. Gomes (2001), Modeling mineral aerosol production by wind erosion: Emission intensities and aerosol size distributions in source areas, J. Geophys. Res., 106(D16), 18,075-18,084.

Brooks, N., and M. Legrand (2000), Dust variability over northern Africa and rainfall in the Sahel, in Linking Climate Change to Land Surface Change, edited by S. McLaren, and D. Kniveton, pp. 1-25, Springer, New York.

Cautenet, G., F. Guillard, B. Marticorena, G. Bergametti, F. Dulac, and J. Edy (2000), Modelling a Saharan dust event, Meteorol. Z., 9, 221-230.

Cotton, W. R., et al. (2003), RAMS 2001: Current status and future directions, Meteorol. Atmos. Phys., 82, 5-29.

Foret, G., G. Bergametti, F. Dulac, and L. Menut (2006), An optimized particle size bin scheme for modeling mineral dust aerosol, J. Geophys. Res., 111, D17310, doi:10.1029/2005JD006797.

Herman, J. R., P. K. Bhartia, O. Torres, C. Hsu, C. Seftor, and E. Celarier (1997), Global distribution of UV-absorbing aerosols from Nimbus7/ TOMS data, J. Geophys. Res., 102(D14), 16,911-16,922.

Holben, B. N., et al. (1998), AERONET - A federated instrument network and data archive for aerosol characterization, Remote Sens. Environ., 66 , $1-16$.

Koren, I., and Y. J. Kaufman (2004), Direct wind measurements of Saharan dust events from Terra and Aqua satellites, Geophys. Res. Lett., 31, L06122, doi:10.1029/2003GL019338.

Koren, I., Y. J. Kaufman, R. Washington, M. C. Todd, Y. Rudich, J. V. Martins, and D. Rosenfeld (2006), The Bodélé depression: A single spot in the Sahara that provides most of the mineral dust to the Amazon forest, Environ. Res. Lett., 1, 014005, doi:10.1088/1748-9326/1/1/014005.

Laurent, B. (2005), Simulation des émissions d'aérosols désertiques à l'échelle continentale: Analyse climatologique des émissions du nordest de l'Asie et du nord de l'Afrique, Ph.D. thesis, 225 pp., Univ. Paris XII, Paris, France, 14 Dec.

Marticorena, B., and G. Bergametti (1995), Modeling the atmospheric dust cycle: 1. Design of a soil-derived dust emission scheme, J. Geophys. Res., 100(D8), 16,415-16,430.

Marticorena, B., G. Bergametti, D. Gillette, and J. Belnap (1997), Factors controlling threshold friction velocity in semiarid and arid areas of the United States, J. Geophys. Res., 102(D19), 23,277-23,287.

Mass, C. F., D. Ovens, K. Westrick, and B. A. Cole (2002), Does increasing horizontal resolution produce more skillful forecasts? The results of two years of real-time numerical weather prediction over the Pacific Northwest, Bull. Am. Meteorol. Soc., 83, 407-430.
Prospero, J. M., P. Ginoux, O. Torres, S. E. Nicholson, and T. E. Gill (2002), Environmental characterization of global sources of atmospheric soil dust identified with the Nimbus 7 Total Ozone Mapping Spectrometer (TOMS) absorbing aerosol product, Rev. Geophys., 40(1), 1002, doi:10.1029/2000RG000095.

Tegen, I., and I. Fung (1995), Contribution to the atmospheric mineral aerosol load from land surface modification, J. Geophys. Res., 100(D9), 18,707-18,726.

Tegen, I., B. Heinold, M. Todd, J. Helmert, R. Washington, and O. Dubovik (2006), Modelling soil dust aerosol in the Bodélé depression during the BoDEx campaign, Atmos. Chem. Phys., 6, 4345-4359.

Todd, M. C., R. Washington, J. V. Martins, O. Dubovik, G. Lizcano, S. M'Bainayel, and S. Engelstaedter (2007), Mineral dust emission from the Bodélé Depression, northern Chad, during BoDEx 2005, J. Geophys. Res., 112, D06207, doi:10.1029/2006JD007170.

Washington, R., and M. C. Todd (2005), Atmospheric controls on mineral dust emission from the Bodélé depression, Chad: The role of the low level jet, Geophys. Res. Lett., 32, L17701, doi:10.1029/2005GL023597. Washington, R., M. C. Todd, S. Engelstaedter, S. M'Bainayel, and F. Mitchell (2006), Dust and the low-level circulation over the Bodélé Depression, Chad: Observations from BoDEx 2005, J. Geophys. Res., 111, D03201, doi:10.1029/2005JD006502.

Washington, R., M. C. Todd, N. J. Middleton, and A. S. Goudie (2003), Dust-storm source areas determined by the Total Ozone Monitoring Spectrometer and surface observations, Ann. Assoc. Am. Geogr., 93, 297-313.

Zhang, J., and S. A. Christopher (2003), Longwave radiative forcing of Saharan dust aerosols estimated from MODIS, MISR, and CERES observations on Terra, Geophys. Res. Lett., 30(23), 2188, doi:10.1029/ 2003 GL018479.

G. Bergametti and B. Marticorena, Laboratoire Interuniversitaire des Systèmes Atmosphériques, UMR CNRS 7583, Université Paris 12 61 Avenue du Général de Gaulle, F-94010 Créteil, France.

C. Bouet and G. Cautenet, Laboratoire de Météorologie Physique, UMR CNRS 6016, Université Blaise Pascal, 24 Avenue des Landais, F-63170 Aubière, France. (c.bouet@opgc.univ-bpclermont.fr)

B. Laurent, Leibniz-Institute for Tropospheric Research, Permoserstrasse 15, D-04318 Leipzig, Germany.

M. C. Todd, Department of Geography, University College London, Pearson Building, Gower Street, London WC1E 6BT, UK.

R. Washington, Climate Research Lab, Centre for the Environment, Oxford University, South Parks Road, Oxford OX1 3QY, UK. 